\title{
Demonstration of Anti-Bacterial Activity of commonly available Fruit Extracts in Dhaka, Bangladesh
}

\author{
Jannatun Tahera, Farahnaaz Feroz, Jessica Das Senjuti, Kamal Kanta Das, Rashed Noor* \\ Department of Microbiology, Stamford University Bangladesh, 51 Siddeswari Road, Dhaka, Bangladesh \\ *Corresponding author: noor.rashed@yahoo.com
}

Received February 25, 2014; Revised March 12, 2014; Accepted March 25, 2014

\begin{abstract}
Present study attempted to determine the antimicrobial activity of extracts from commonly consumed fruits including guava (Psidium guajava), malta (Citrus sinensis), apple (Malus domestica), orange (Citrus reticulate) and dragon fruit (Hylocereus polyrhizus) against Bacillus spp., Pseudomonas spp., Vibrio spp., Escherichia coli, Klebsiella spp., Staphylococcus spp., Listeria spp., Salmonella spp., and Aeromonas spp. Of the fruits examined, malta and orange samples were observed to be most effective against the test organisms, whereas dragon fruit was the least effective one. Among all the bacteria tested, Bacillus spp. seemed to be most susceptible to the antibacterial activity of the fruits, whereas Aeromonas spp. seemed to be the most resistant one. No significant difference in antimicrobial activity was observed among the imported and local fruit extracts.
\end{abstract}

Keywords: anti-bacterial activity, microorganisms, fruit extracts, public health

Cite This Article: Jannatun Tahera, Farahnaaz Feroz, Jessica Das Senjuti, Kamal Kanta Das, and Rashed Noor, "Demonstration of Anti-Bacterial Activity of commonly available Fruit Extracts in Dhaka, Bangladesh." American Journal of Microbiological Research, vol. 2, no. 2 (2014): 68-73. doi: 10.12691/ajmr-2-2-5.

\section{Introduction}

Recent increase in the commencement of infectious diseases, principally due to environmental malpractice has led to the microbiological contamination of an array of raw and processed food items, with an elevated level of drug-resistant bacteria [1,2]. Such a public health threat has accelerated the quest for new and innovative natural means of combating bacterial pathogens including Escherichia coli, Salmonella spp., Listeria monocytogenes, Aeromonas spp., Staphylococcus spp., Streptococcus spp., Vibrio spp., Pseudomonas spp. and others [2,3,4]. Fruits are well known for their health benefits, due to their nutrient contents and bioactive components with a considerable amount of saccharides, polyphenolic compounds and minerals [5-10]. Several reports have shown the antimicrobial potential of plants while a range of fruits, particularly those rich in Vitamin C, and plants containing flavonoids, terpenoids, steroids, phenolic compounds and alkaloids to be effective against various infections including enteritis, arthritis, cardiac complications, etc [9,10,11,12,13].

The mass usage of non-prescribed medicines, discrepancies in waste management, natural transfer of drug-resistance genes and finally the lack of regulation in antibiotic usage led to the onset of complications related to drug-resistance especially in the developing countries including Bangladesh with a relatively poor management of healthcare system $[14,15,16,17]$. Such a situation could demand for alternative natural medication approaches with least toxicity and side effects [18-25]. In Bangladesh, an array of medicinal plants have so far been reported with their effectiveness; however, work on fruits is still insignificant [19]. Along these lines, current investigation attempted (i) to determine the anti-bacterial activity of aqueous and alcoholic extracts from commonly consumed fruits including guava, malta, apple, orange and dragon fruits, and (ii) also to compare the activity among the local and imported samples..

\section{Materials and Methods}

\subsection{Sampling}

Guava (Psidium guajava), malta (Citrus sinensis), apple (Malus domestica), orange (Citrus reticulate) and dragon fruit (Hylocereus polyrhizus) samples were used in the current study. Local fruits were purchased from street vendors or local groceries of Dhaka, Bangladesh and the imported ones were purchased from supermarkets in Dhaka. All the samples were collected early in the morning and transported quickly to the laboratory and processed immediately [26].

\subsection{Preparation of Fruit Extracts}

Fruits were cut into thin pieces, skin and flesh were separated and air-dried at $37^{\circ} \mathrm{C}$ up to 4 days. Dried samples were then ground into fine powder and washed with distilled water, ethanol and methanol (with a ratio of 1: 10 each), consecutively $[2,27]$. The crude extracts were placed in a bio shaker (Daihan Scientific Co., Ltd, Korea, Model No-WSB-30) set at $20^{\circ} \mathrm{C}$ with shaking at $130 \mathrm{rpm}$ overnight $[2,28]$. The liquid samples were then aseptically filtered with Whatman filter paper no. 2 (Hangzhou 
Xinhua Paper Industry Co., Ltd., Hangzhou, China). The remaining residual materials were further dried at $40^{\circ} \mathrm{C}$ overnight, and concentrated using a rotary vacuum evaporator [2]. The concentrated samples were further diluted to $10 \mathrm{mg} / \mathrm{mL}$ with 10\% dimethyl sulfoxide (Merck,

India) and filtered using. $0.45 \mu \mathrm{m}$ filter [2,29]. Samples were stored at $-20^{\circ} \mathrm{C}$ until further use [2,27].

\subsection{Assay of Antimicrobial Activity}

Table 1. Antimicrobial Activity of Local and Imported Guava Extracts

\begin{tabular}{|c|c|c|c|c|c|c|c|c|c|c|c|}
\hline & \multirow[b]{2}{*}{ Fruit samples } & \multirow[b]{2}{*}{ Sample extracts } & \multicolumn{9}{|c|}{ Zone of inhibition (mm) against test bacteria } \\
\hline & & & 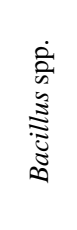 & 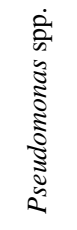 & 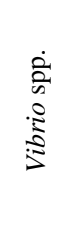 & 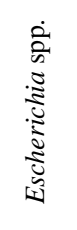 & 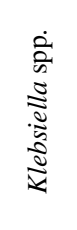 & 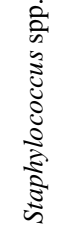 & 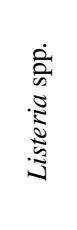 & 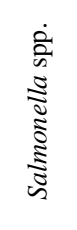 & 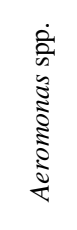 \\
\hline \multirow{9}{*}{ 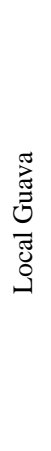 } & \multirow{3}{*}{ Skin } & Aqueous & 11.0 & 0 & 9.90 & 10 & 0 & 0 & 13 & 0 & 0 \\
\hline & & Ethanol & 8.71 & 8.20 & 9.42 & 9.4 & 8.84 & 9.25 & 12.14 & 11 & 0 \\
\hline & & Methanol & 12.80 & 7.80 & 0 & 0 & 0 & 0 & 11.20 & 0 & 0 \\
\hline & \multirow{3}{*}{ Core } & Aqueous & 10.0 & 13.0 & 0 & 0 & 12 & 0 & 14 & 0 & 10.50 \\
\hline & & Ethanol & 9.27 & 11.69 & 10.71 & 10.20 & 10.64 & 8.84 & 13.01 & 0 & 0 \\
\hline & & Methanol & 0 & 10.0 & 7.20 & 0 & 10 & 0 & 11 & 7.0 & 0 \\
\hline & \multirow{3}{*}{ Skin and core combined } & Aqueous & 16.0 & 11.0 & 0 & 10 & 0 & 9.0 & 0 & 10.30 & 9.80 \\
\hline & & Ethanol & 13.0 & 9.84 & 0 & 0 & 9.14 & 9.21 & 0 & 0 & 0 \\
\hline & & Methanol & 19.27 & 10.95 & 0 & 9.13 & 8.70 & 0 & 0 & 0 & 0 \\
\hline \multirow{9}{*}{ 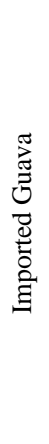 } & \multirow{3}{*}{ Skin } & Aqueous & 14.0 & 0 & 0 & 0 & 0 & 9.50 & 0 & 0 & 0 \\
\hline & & Ethanol & 10.70 & 0 & 0 & 8.21 & 0 & 9.0 & 9.40 & 9.30 & 0 \\
\hline & & Methanol & 12.0 & 0 & 0 & 0 & 0 & 0 & 12.20 & 0 & 0 \\
\hline & \multirow{3}{*}{ Core } & Aqueous & 11.0 & 9.0 & 0 & 0 & 9.50 & 0 & 0 & 0 & 11 \\
\hline & & Ethanol & 7.91 & 0 & 8.70 & 9.30 & 10.27 & 9.97 & $0-$ & 0 & 0 \\
\hline & & Methanol & 10.18 & 0 & 0 & 0 & 0 & 0 & 10.90 & 0 & 0 \\
\hline & \multirow{3}{*}{ Skin and core combined } & Aqueous & 0 & 0 & 0 & 10 & 0 & 0 & 0 & 0 & 0 \\
\hline & & Ethanol & 8.23 & 0 & 0 & 9.97 & 0 & 9.25 & 10 & 0 & 0 \\
\hline & & Methanol & 10.56 & 10.24 & 0 & 0 & 0 & 7.50 & 11.55 & 0 & 0 \\
\hline
\end{tabular}

Antimicrobial activity was determined by using the agar well diffusion methods as described by Fadipe et al., [13]. Antimicrobial activities of the fruit blends, the skin extracts, and the extracts of fruit flesh were carried out separately. Suspensions of the laboratory test strains of microorganisms (Bacillus spp., Pseudomonas spp., Vibrio spp., Escherichia coli, Klebsiella spp., Staphylococcus spp., Listeria spp., Salmonella spp., and Aeromonas spp.) were prepared using normal saline, consisting of $10^{6}$ colony forming units per $\mathrm{mL}(\mathrm{cfu} / \mathrm{mL})$ with a turbidity equivalent to that of the $0.5 \mathrm{~mL}$ McFarland standard, and each suspension was then subject to lawn on the MullerHinton agar (MHA) (Oxoid Ltd., Basingstoke, Hampshire, England). After the inoculum dried off, wells $\left(8 \mathrm{~mm}^{3}\right)$ were prepared using sterile cork borers. A volume of 100 $\mu \mathrm{L}(\sim 10 \mathrm{mg} / \mathrm{mL})$ of each extract was placed into separate wells, dried and then incubated at $37^{\circ} \mathrm{C}$ overnight. Normal saline and the antibiotic discs of Gentamicin $10 \mu \mathrm{g}$ or Streptomycin $10 \mu \mathrm{g}$ (Oxoid, England) were used as negative and positive controls, respectively [2]. Plates were incubated at $37^{\circ} \mathrm{C}$ for 12 hours, and then examined for the appearance of the zone ( $\mathrm{mm}$ ) of inhibitions (if any). Experiments were performed in triplicate and the results were reproducible. One representative data have been chosen in each case.

\section{Results}

\subsection{Anti-Bacterial Activity of Guava Extracts}

Both the parts of local guava samples inhibited most of the bacterial growth, especially to a greater extent in case of Bacillus spp. and Pseudomonas spp. despite of the extraction method (Table 1). Extended anti-bacterial activity was observed after ethanol extraction eventually for the separate skin and core portions than their combined extracts. However, when the skin and core were combined, much better results were found by the aqueous extracts. Less efficiency was observed in case of inhibiting the growth of Aeromonas spp. and Salmonella spp. Interestingly, zone of inhibition was absent in cases of Vibrio spp. and Listeria spp. in the combined extract although their growth were frequently inhibited by extracts of skin or core individually. Such a discrepancy could be an experimental artifact, or might be due to the possible limited secretion of active compounds in case of whole blend extracts. Further experiments regarding identification of antimicrobials within the fruits could unveil this incongruity. Minimal antibacterial activity was monitored for the imported guava samples compared to the local ones. Like local guava samples, imported 
samples could successfully inhibit the growth of Bacillus spp. but merely could affect the growth of Aeromonas spp. Vibrio spp. and Salmonella spp. (Table 1). Unlike the local samples, the skin portions exhibited no activity against Pseudomonas spp. However, an elevated antibacterial activity was found after ethanol extraction.

3.2. Anti-Bacterial Activity of Apple Extracts

Table 2. Antimicrobial Activity of Local and Imported Apple Extracts (mm)

\begin{tabular}{|c|c|c|c|c|c|c|c|c|c|c|c|}
\hline & \multirow[b]{2}{*}{ Fruit Samples } & \multirow[b]{2}{*}{ Sample Extracts } & \multicolumn{9}{|c|}{ Zone of inhibition (mm) against test bacteria } \\
\hline & & & $\begin{array}{l}\dot{\hat{n}} \\
\dot{n}\end{array}$ & $\begin{array}{l}\dot{\hat{े}} \\
\hat{\tilde{z}} \\
\dot{\Xi}\end{array}$ & किं & 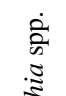 & 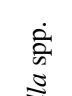 & $\begin{array}{l}\text { चि } \\
\tilde{\Xi} \\
\tilde{U}\end{array}$ & के & $\begin{array}{l}\hat{\tilde{A}} \\
\stackrel{0}{=}\end{array}$ & $\begin{array}{l}\hat{\hat{n}} \\
\text { चे }\end{array}$ \\
\hline \multirow{9}{*}{ 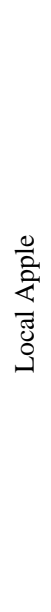 } & \multirow{3}{*}{ Skin } & Aqueous & 11.0 & 16.0 & 9.0 & 0 & 0 & 0 & 10.0 & 0 & 9.0 \\
\hline & & Ethanol & 0 & 12.0 & 7.5 & 10.0 & 9.0 & 9.5 & 0 & 0 & 0 \\
\hline & & Methanol & 9.70 & 10.0 & 0 & 0 & 0 & 0 & 0 & 9.20 & 0 \\
\hline & \multirow{3}{*}{ Core } & Aqueous & 12.70 & 13.0 & 0 & 9.0 & 11.60 & 0 & 9.70 & 0 & 0 \\
\hline & & Ethanol & 10.35 & 11.25 & 0 & 0 & 0 & 10.0 & 0 & 9.30 & 7.50 \\
\hline & & Methanol & 14.70 & 9.20 & 9.90 & 0 & 9.14 & 0 & 0 & 0 & 0 \\
\hline & \multirow{3}{*}{ Skin and Core Combined } & Aqueous & 12.40 & 10.90 & 8.50 & 0 & 7.10 & 0 & 0 & 7.80 & 8.10 \\
\hline & & Ethanol & 7.20 & 9.70 & 0 & 0 & 7.0 & 0 & 0 & 0 & 0 \\
\hline & & Methanol & 0 & 0 & 10.20 & 0 & 9.27 & 0 & 0 & 0 & 0 \\
\hline \multirow{9}{*}{ 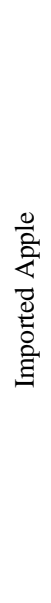 } & & Aqueous & 10.0 & 12.0 & 0 & 0 & 9.60 & 8.50 & 0 & 0 & 0 \\
\hline & Skin & Ethanol & 7.30 & 9.0 & 0 & 0 & 7.50 & 0 & 0 & 0 & 0 \\
\hline & & Methanol & 0 & 7.50 & 0 & 0 & 0 & 0 & 0 & 11.0 & 10.70 \\
\hline & \multirow{3}{*}{ Core } & Aqueous & 13.02 & 0 & 0 & 0 & 12.0 & 9.43 & 0 & 10.0 & 0 \\
\hline & & Ethanol & 7.25 & 12.0 & 0 & 0 & 0 & 0 & 0 & 0 & 0 \\
\hline & & Methanol & 8.90 & 11.70 & 9.0 & 0 & 9.15 & 0 & 9.05 & 8.27 & 0 \\
\hline & \multirow{3}{*}{ Skin and Core Combined } & Aqueous & 13.0 & 12.50 & 0 & 0 & 8.20 & 0 & 7.10 & 0 & 0 \\
\hline & & Ethanol & 10.40 & 0 & 7.0 & 0 & 0 & 0 & 0 & 0 & 0 \\
\hline & & Methanol & 9.15 & 0 & 0 & 0 & 9.34 & 0 & 0 & 0 & 0 \\
\hline
\end{tabular}

Both local and imported apple samples showed inhibitory effects frequently against Bacillus spp., Pseudomonas spp. and Klebsiella spp. (Table 2). Least extent of anti-bacterial activity was found against Salmonella spp., Staphylococcus spp., Aeromonas spp., Vibrio spp. and Listeria spp. in both samples. Although to a lower extent, the local samples inhibited the growth of $E$. coli; while imported sample showed no effect on them (Table 2). However, skin and core portion showed higher anti-bacterial activity against the tested bacteria in comparison to their combinations. Imported apple samples showed lower anti-bacterial effectiveness with the ethanol extract in comparison to the aqueous and methanol extracts. As has been seen in case of guava samples, the local apple samples also showed the better anti-bacterial activity than that of the imported ones.

\subsection{Anti-Bacterial Activity of Orange Extracts}

The peel portion of the orange sample showed extended antibacterial activity after extraction with ethanol and methanol (Table 3). Meanwhile, the core portion was found to be effective against some bacteria with the aqueous extraction and onward with ethanol extraction. As apple samples, orange samples also exhibited greater antibacterial activity against Klebsiella spp., Bacillus spp. and Pseudomonas spp. Lesser extent of antimicrobial activity was observed against Vibrio spp., E. coli and Salmonella spp. in both local and imported samples (Table 3). Although the ethanol extracts of local orange samples inhibited the growth of Staphylococcus spp., the strains were found to be unaffected by the imported apple extracts. Both the samples imparted no anti-bacterial against Aeromonas spp. Like both guava and apple samples, the local orange samples exhibited enhanced anti-bacterial activity after the addition of ethanol and methanol than the imported orange samples. 
Table 3. Antimicrobial Activity of Local and Imported Orange Extracts (mm)

\begin{tabular}{|c|c|c|c|c|c|c|c|c|c|c|c|}
\hline \multirow{2}{*}{\multicolumn{2}{|c|}{$\begin{array}{l}\text { Fruit Sample } \\
\text { Components }\end{array}$}} & \multirow[b]{2}{*}{ Sample Extracts } & \multicolumn{9}{|c|}{ Zone of inhibition (mm) against test bacteria } \\
\hline & & & $\begin{array}{l}\dot{\hat{े}} \\
\hat{\hat{n}} \\
\stackrel{\Xi}{\Xi}\end{array}$ & $\begin{array}{l}\dot{2} \\
\text { के } \\
\tilde{\Xi} \\
\tilde{\Xi}\end{array}$ & $\begin{array}{l}\dot{\hat{ि}} \\
\text { के }\end{array}$ & 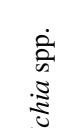 & $\begin{array}{l}\dot{\hat{ि}} \\
\text { के } \\
\stackrel{\tilde{\sigma}}{\approx}\end{array}$ & $\begin{array}{l}\dot{\hat{n}} \\
\tilde{n} \\
\tilde{\Xi} \\
\tilde{\delta}\end{array}$ & $\begin{array}{l}\dot{\hat{\theta}} \\
\text { क्. }\end{array}$ & $\begin{array}{l}\dot{\hat{~}} \\
\stackrel{\tilde{n}}{\tilde{\Xi}}\end{array}$ & $\begin{array}{l}\dot{\hat{ि}} \\
\hat{n} \\
\tilde{\Xi}\end{array}$ \\
\hline \multirow{6}{*}{ 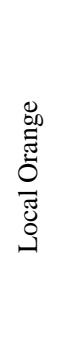 } & \multirow{3}{*}{ Peel } & Aqueous & 0 & 0 & 0 & 11.0 & 7.0 & 0 & 0 & 0 & 0 \\
\hline & & Ethanol & 9.40 & 9.20 & 0 & 9.70 & 12.43 & 0 & 0 & 11.10 & 0 \\
\hline & & Methanol & 0 & 10.70 & 8.10 & 0 & 9.20 & 0 & 7.90 & 7.50 & 0 \\
\hline & \multirow{3}{*}{ Core } & Aqueous & 15.8 & 10.70 & 0 & 9.40 & 13.5 & 0 & 0 & 0 & 0 \\
\hline & & Ethanol & 0 & 0 & 0 & 11.96 & 9.55 & 9.80 & 12.40 & 9.90 & 0 \\
\hline & & Methanol & 12.40 & 0 & 0 & 0 & 0 & 0 & 7.80 & 0 & 0 \\
\hline \multirow{6}{*}{ 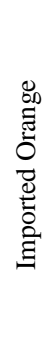 } & \multirow{3}{*}{ Peel } & Aqueous & 13.0 & 10.0 & 0 & 0 & 9.0 & 0 & 0 & 0 & 0 \\
\hline & & Ethanol & 11.50 & 11.23 & 0 & 0 & 11.20 & 0 & 0 & 7.0 & 0 \\
\hline & & Methanol & 0 & 0 & 8.95 & 0 & 9.80 & 0 & 9.02 & 9.35 & 0 \\
\hline & \multirow{3}{*}{ Core } & Aqueous & 10.70 & 0 & 0 & 11.20 & 0 & 0 & 7.10 & 0 & 0 \\
\hline & & Ethanol & 9.80 & 7.30 & 0 & 0 & 10.25 & 0 & 8.45 & 0 & 0 \\
\hline & & Methanol & 13.20 & 7.0 & 0 & 0 & 8.04 & 0 & 0 & 0 & 0 \\
\hline
\end{tabular}

\subsection{Anti-Bacterial Activity of Malta Extracts}

In local Malta sample, better zone of inhibition was found in the core/ peel portions regardless of the extraction method (Table 4). Like other fruit samples, an extended anti-bacterial potential was also observed in the local malta compared to the imported malta sample, especially against Bacillus spp. Pseudomonas spp. Vibrio spp. and Staphylococcus spp. As in the other samples, growth of Aeromonas spp. was not inhibited by both the local and imported malta samples (Table 4). Minimal antibacterial activity was observed against Salmonella spp. The imported malta samples showed less anti-bacterial activity against Pseudomonas spp., Vibrio spp. and Salmonella spp. No inhibitory effect was found against Listeria spp. in the imported samples; while peel portions of the local malta inhibited their growth (Table 4).

Table 4. Antimicrobial Activity of Malta (mm)

\begin{tabular}{|c|c|c|c|c|c|c|c|c|c|c|c|}
\hline \\
\hline \multirow{2}{*}{\multicolumn{2}{|c|}{ Fruit Sample Components }} & \multirow{3}{*}{$\begin{array}{l}\text { Sample Extracts } \\
\text { Aqueous }\end{array}$} & \multicolumn{9}{|c|}{ Zone of inhibition (mm) against test bacteria } \\
\hline & & & $\dot{\overrightarrow{\hat{n}}}$ & $\begin{array}{l}\dot{\hat{ि}} \\
\hat{\sigma}\end{array}$ & $\dot{\hat{ि}}$ & $\begin{array}{l}\dot{\hat{े}} \\
\stackrel{\tilde{\Xi}}{0}\end{array}$ & $\begin{array}{l}\dot{\hat{ि}} \\
\hat{\mathbf{n}} \\
\text { s}\end{array}$ & 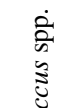 & के & $\begin{array}{l}\dot{\hat{\theta}} \\
\text { a }\end{array}$ & $\begin{array}{l}\dot{\hat{ि}} \\
\hat{y}\end{array}$ \\
\hline \multirow{6}{*}{ Local Malta } & \multirow{3}{*}{ Peel } & & 0 & 14.0 & 7.27 & 0 & 0 & 0 & 11.0 & 0 & 0 \\
\hline & & Ethanol & 10.70 & 13.38 & 0 & 0 & 0 & 7.0 & 9.0 & 0 & 0 \\
\hline & & Methanol & 8.02 & 0 & 9.60 & 0 & 0 & 0 & 0 & 0 & 0 \\
\hline & \multirow{3}{*}{ Core } & Aqueous & 14.0 & 10.0 & 14.30 & 9.80 & 8.0 & 15.0 & 0 & 7.20 & 0 \\
\hline & & Ethanol & 16.04 & 16.10 & 8.70 & 10.90 & 10.50 & 9.0 & 0 & 0 & 0 \\
\hline & & Methanol & 0 & 9.60 & 12.02 & 8.20 & 7.0 & 0 & 0 & 0 & 0 \\
\hline \multirow{6}{*}{ Imported Malta } & \multirow{3}{*}{ Peel } & Aqueous & 10.0 & 0 & 0 & 0 & 11.0 & 0 & 0 & 0 & 0 \\
\hline & & Ethanol & 8.40 & 0 & 7.70 & 0 & 9.20 & 0 & 0 & 0 & 0 \\
\hline & & Methanol & 0 & 9.30 & 0 & 0 & 0 & 0 & 0 & 0 & 0 \\
\hline & \multirow{3}{*}{ Core } & Aqueous & 0 & 7.30 & 0 & 0 & 0 & 10.0 & 0 & 0 & 0 \\
\hline & & Ethanol & 0 & 0 & 0 & 10.84 & 0 & 11.72 & 0 & 13.42 & 0 \\
\hline & & Methanol & 0 & 0 & 0 & 7.50 & 0 & 0 & 0 & 0 & 0 \\
\hline
\end{tabular}


Table 5. Antimicrobial Activity of local and Imported Dragon fruit extracts ( $\mathrm{mm}$ )

\begin{tabular}{|c|c|c|c|c|c|c|c|c|c|c|c|}
\hline \multirow{2}{*}{\multicolumn{2}{|c|}{ Sample Components }} & \multirow{3}{*}{$\begin{array}{l}\text { Extract } \\
\text { Aqueous }\end{array}$} & \multicolumn{9}{|c|}{ Zone of inhibition $(\mathrm{mm})$ against test bacteria } \\
\hline & & & $\begin{array}{l}\dot{\hat{\hat{n}}} \\
\hat{3}\end{array}$ & $\begin{array}{l}\dot{\Delta} \\
\hat{n} \\
\tilde{\Xi} \\
\tilde{\Xi}\end{array}$ & $\begin{array}{l}\hat{\tilde{n}} \\
\text { हे }\end{array}$ & 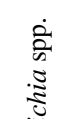 & $\begin{array}{l}\dot{\hat{ि}} \\
\text { के } \\
\stackrel{0}{\approx}\end{array}$ & 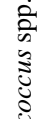 & $\begin{array}{l}\dot{\hat{े}} \\
\text { के }\end{array}$ & 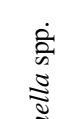 & $\begin{array}{l}\dot{\hat{ि}} \\
\text { के } \\
\text { हे }\end{array}$ \\
\hline \multirow{3}{*}{ Local Dragon Fruit } & \multirow{3}{*}{ Core } & & 15.0 & 0 & 13.0 & 0 & 7.0 & 0 & 0 & 0 & 0 \\
\hline & & Ethanol & 7.50 & 9.02 & 0 & 14.42 & 9.20 & 0 & 0 & 0 & 0 \\
\hline & & Methanol & 0 & 0 & 10.30 & 7.10 & 9.07 & 0 & 10.5 & 10.02 & 0 \\
\hline \multirow{3}{*}{ Imported Dragon Fruit } & \multirow{3}{*}{ Core } & Aqueous & 13.0 & 0 & 0 & 0 & 9.0 & 0 & 0 & 0 & 0 \\
\hline & & Ethanol & 7.80 & 9.90 & 0 & 13.50 & 9.83 & 0 & 9.10 & 8.40 & 0 \\
\hline & & Methanol & 7.80 & 7.50 & 9.70 & 7.0 & 9.20 & 0 & 9.0 & 0 & 0 \\
\hline
\end{tabular}

\subsection{Anti-Bacterial Activity of Dragon Fruit Extracts}

The ethanol and methanol extracts showed an overall better anti-bacterial activity than those of the aqueous extracts (Table 5). Enhanced anti-bacterial activity was noticed in the local dragon fruit samples against Bacillus spp., Vibrio spp., E. coli and Staphylococcus spp. (Table 5). However, the growth of Aeromonas spp. and Staphylococcus spp. were not inhibited by both the local and imported samples (Table 5).

\section{Discussion}

The increased nutritional benefits with least side effects of fruits promoted their use for medicinal purposes regarding the regulated management of public health [1825]. As stated earlier, the incidence of drug resistance has risen in recent times not only due the natural dissemination of resistance genes but also because of excess use and abuse of antimicrobial drugs $[14,15,16,17,18]$. This threat to public health has contributed to the increased interests in the development of natural antimicrobial agents, with a lack of adverse side effects. In our study, samples included both local and imported fruits, available in Dhaka city, in an attempt to compare the activities of fruits grown at home and abroad. Interestingly, no significant difference was observed among imported and local fruits, indicating, regardless of origin, the anti-microbial effect of the fruits on microbes remained the same.

According to our findings, separate extracts of skin and core of local guava samples were highly effective against Listeria spp., while the extracts of whole fruits were most effective against Bacillus spp. (Table 1). Results for imported and local apples were similar to that of the guava samples (Table 2). The lowest activity of apple and guava extracts was observed against Klebsiella spp., Salmonella spp., and Listeria spp., while the activity was strongest against Bacillus spp., Klebsiella spp., and Psuedomonas spp. Conversely both the orange and malta showed intermediate to no antimicrobial activity against Aeromonas spp., Salmonella spp., and Staphylococcus spp. (Table 3 and Table 4). Dragon fruit extracts showed antibacterial activity against Bacillus spp. and E. coli (Table 5). For most of the cases the anti-bacterial activity was found to be the highest in the cases of aqueous and ethanol extracts and low for the other extracts. Notably, the repeated process of extractions might decrease the anti- bacterial activity, and the finals extracts
presumptively exhibited no antimicrobial activity.

More specifically, in most cases a comparatively elevated antimicrobial activity was observed in aqueous extracts, which could indicate that the activity was due to the compounds of the fruits rather than the solvents. We assume that the extraction of the tested fruits in water first might lower the chance of the same substances to be completely extracted in the organic solvents (methanol and ethanol). Additionally, although ethanol and methanol was added, some samples showed the decrease in the antibacterial activity upon each extraction phase. Interestingly, previous studies have reported higher activities in methanol extracts, and subsequently presented it as the better solvent for use in extraction processes [13].

Our results are partially coherent with the previous studies with the apple extracts as the susceptibility was observed in Pseudomonas spp. [5,10]. As reported earlier, the phytoconstituents of the samples studied are expected to contribute immensely to their anti-bacterial traits [13]. Additionally, our samples were all unripe; therefore they might possess higher levels of tannins and alkaloids, exerting cytotoxicity towards bacterial cells [30]. Experimental demonstration of the active compounds would further directly lineate the mechanism of antibacterial activity. Arora and Kaur found nearly similar results as revealed from our study especially in case of orange peel against $E$. coli (with an inhibition zone size of 6-11 mm); however, their findings for Staphylococcus were significantly higher than the current study [31]. Both studies have deduced the higher levels anti-bacterial activity in case of pulp; nevertheless, did not rule out the use of those peels for medicinal purposes. Water extracts of dragon fruit flesh revealed susceptibility against a few organisms, but for most pathogens, no zone of inhibition was observed.

Overall, the practice of natural medication employing herbs are globally accepted in respect to the treatment efficiency with minute side effects [11,16,19,20,21,22,23]. The anti-bacterial activities as found in the current investigation both in case of imported and local fruit extracts further demonstrate the therapeutic value of natural products. Our study has been able to demonstrate the effectiveness of fruits against a range of microbes. Overall, the study encourages the consumption of fruits in combating pathogenic microorganisms as an alternative to the anti-bacterial drugs and hence to aid to the better management of public health associated risks. 


\section{Acknowledgement}

We would like to thank Stamford University Bangladesh for providing us with the laboratory facilities and financial support.

\section{Conflict of Interest}

Authors have declared that no competing interests exist.

\section{References}

[1] Dharmishtha, M. and Falguni, G., "Antibacterial activity of methanolic fruit extract of randia dumetrum lamk,” Int J Pharm Tech Resl 2009, 1, 679-681.

[2] Hoque, M.D.M., Bari, M.L., Inatsu, Y., Juneja, V.K. and Kawamoto, S., "Antibacterial activity of guava (Psidium guajava L.) and neem (Azadirachta A. Juss) extracts against foodborne pathogens and spoilage bacteria,” Foodborne pathog Dis, 2007, 4, 481-488.

[3] Fadipe, L.A., Haruna, K., Mohammed, I. and Ibikunle, G.F., "Phytochemical and in-vitro antibacterial evaluation of the extracts, portions and sub-portions of the ripe and unripe fruits of Nauclea latifolia,” J Medicinal Plant Res, 2013, 7, 629-636.

[4] Sivapriya, M., Harsha, D.R., Gowda, S.S.T. and Srinivas, L., "Antibacterial Activity of Different Extracts of Sundakai (Solanum torvum) Fruit Coat," Int J Biol Chem 2011, 5, 61-67.

[5] Jelodarian, S., Ebrahimabadi, A.H. and Kashi, F.J., "Evaluation of antimicrobial activity of Malus domestica fruit extract from Kashan area,” Avicenna J Phytomed, 2013, 3, 1-6.

[6] Prakas, P. and Kumar, N., "Design and development of sustained reease matris tablet of diclofena sodium using natural polymer," Int Res J Pharm, 2013, 4, 169-176.

[7] Sibi, G., Kaushik, K., Dhananjaya, K., Ravikumar, K.R. and Mallesha, H., "Antibacterial activity of Sechium edule (Jacq.) Swartz against Gram negative food borne bacteria,” Adv Appl Sci Res, 2013, 4, 259-261

[8] Ghasemi, P., Momeni, A. and Bahmani, M., "Ethnobotanical study of medicinal plants used by Kurd tribe in Dehloran and Abdanan districts,” Ilam Provinve, Iran. Afr J Trad Complement Altern Med, 2013, 10, 368-385.

[9] Umer, A., Tekewe, A. and Kebede, N., "Antidiarrhoel and antimicrobial activity of Calpurnia aurea leaf extract," BMC Complemen Altern Med, 2013, 13, 21.

[10] Naseer, U., Hajera, T., Ali, M.N. and Ponia, K., "Evaluation of antibacterial activity of five selected fruits on bacterial wound isolates,” Int J Pharma Bio Sci, 2012, 3, 531-546.

[11] Iwu, M.W., Duncan, A. and Okunji, C.O., New antimicrobials of plant origin. In: Janick J, Editor. Perspectives on new crops and new uses, Alexandria: ASHS Press, 1999.

[12] Chanda, S., Baravalia, Y., Kaneria, M. and Rakholiya, K., "Fruit and vegetable peels - strong natural source of antimicrobics," Current Res Technol Edu Topics Appl Microbiol Microbial Biotechnol, 2010, 444-450.

[13] Fadipe, L.A., Haruna, K., Mohammed, I. and Ibikune, G.F., "Phytochemical and in-vitro antibacterial evaluation of the extracts, portions and sub-portions of the ripe and unripe fruits of Nauclea latifolia,” J Med Plants Res, 2013, 7, 629-636.

[14] Djeussi, D.E., Noumedem, J.A.K., Seukep, J.A., Fankam, A.G., Voukeng, I.K., Tankeo, S.B. and et al., "Antibacterial activities of selected edible plants extracts against multidrug-resistant Gramnegative bacteria,” BMC Complemen Altern Med, 2013, 13, 164.

[15] Dutta, S., Hassan, M.R., Rahman, F., Jilani, M.F.A. and Noor, R., "Study of antimicrobial susceptibility of clinically significant microorganims isolated from selected areas of Dhaka, Bangladesh,” Bang J Med Sci, 2013, 12: 34-42.

[16] Izzo, A.A. and Ernst, E., "Interactions between herbal medicines and prescribed drugs: an updated systematic review,” Drugs 2009, 69, 1777-98.

[17] Molton, J.S., Tambyah, P.A., Ang, B.S., Ling, M.L. and Fisher, D.A., "The global spread of healthcare-associated multidrugresistant bacteria: a perspective from Asia,” Clin Infect Dis, 2013, 56, 1310-8.

[18] Cragg, G.M. and Newman, D.J., "Natural products: a continuing source of novel drug leads,” Biochim Biophys Acta, 2013, 1830, 3670-3695.

[19] Protiva, R.D., Islam, M.T., Mahmud, A.S.M.S.B., Kabir, M.H., Hasan, M.E., Khatun, Z. and et al., "An ethnomedicinal survey conducted among the folk medicinal practitioners of three villages in Kurigram district, Bangladesh,” American-Eurasian J Sustain Agri, 2012, 6, 85-96.

[20] Veeresham, C., "Natural products derived from plants as a source of drugs," J Adv Pharma Tech Res, 2012, 3, 200-201.

[21] Damery, S., Gratus, C., Grieve, R., Warmingtons, S., Jones, J., Routledge, P. and et al., "The use of herbal medicines by people with cancer: a cross-sectional survey,” Br J Cancer, 2011, 104, 927-933.

[22] Ernst, E., "Herbal medicine in the treatment of rheumatic diseases,” Rheumatic Dis Clin North Ame, 2011, 37, 95-102.

[23] Gyasi, R.M., Charlotte, M.M., Prince, O.W.A. and Seth, A., "Public Perceptions of the Role of Traditional Medicine in the Health Care Delivery System in Ghana," Global J Health Sci, 2011, 3, 40-49.

[24] Kraft, K., "Complementary/Alternative Medicine in the context of prevention of disease and maintenance of health," Prev Med, 2009, $49,88-92$.

[25] 25. Mendes, E., Herdeiro, M.T. and Pimentel. F., and "The use of herbal medicine therapies by cancer patients,” Act Med Port 2010, 23, 901-8.

[26] American Public Health Association, Standard methods for the examination of water and wastewater, Washington, D.C., American Public Health Association, 1998.

[27] Movalia, D. and Gajera, F., "Antibacterial Activity of methanolic fruit extract of randia dumetorum lamk," Int J Pharmtech Res, 2009, 1, 679-681.

[28] Abdulla, A.H., Mirghani, M.E.S. and Jamal, P., "Antibacterial activity of Malaysian mango kernel,” African J Biotechnol, 2011, 10, 18739-18748.

[29] Sivapriya, M., Dinesha, R., Harsha, R., Gowda, S.S.T. and Srinivas, L., "Antibacterial Activity of Different Extracts of Sundakai (Solanum torvum) Fruit coat,” Int J Bio Chem, 2011, 5, 61-67.

[30] Jones, G.A., McAlysisllister, T.A., Muir, A.D. and Cheng, K.J., "Effects of sainfoin (Onobrychis vicifolia Scup.) condensed tannins on growth and proteolysis by four strains of ruminal bacteria,” Appl Environ Microbiol, 1994, 60, 1374-1378.

[31] Arora, M. and Kaur, P., "Antimicrobial and antioxidant activity of orange pulp and peel,” Int J Sci Res, 2013, 2, 412-4. 